\title{
Levofloxacin-based Triple Therapy for Eradicating Helicobacter pylori and Effect of its Drug Concentration
}

\author{
$\mathrm{YM} \mathrm{Hu}^{1,2}, \mathrm{LL} \mathrm{Luo}^{3}, \mathrm{XP} \mathrm{Hu}{ }^{3}, \mathrm{JM} \mathrm{Xu}^{3}, \mathrm{~L}_{\text {Zhang }}{ }^{2,3}$
}

\begin{abstract}
Objectives: This study aimed to investigate seven and ten-day courses of levofloxacin-based triple therapy and the effect of levofloxacin concentration in gastric mucosa on Helicobacter pylori ( $\mathrm{Hp}$ ) eradication.

Methods: Levofloxacin (500 $\mathrm{mg} q \mathrm{qd}$ ), esomeprazole $(20 \mathrm{mg}$ bid) and amoxicillin (1000 $\mathrm{mg}$ bid) were used to treat 240 Hp-positive chronic gastritis patients. Patients were randomly divided into seven and ten days treatment groups ( $n=120$ in each group). The carbon dioxide-14 $\left({ }^{14} \mathrm{C}\right)$ breath tests of the patient were reviewed four weeks after the end of the eradication treatment. On the first day after the treatment, four blocks of gastric antrum mucosa were obtained from 61 patients of the seven-day group to determine levofloxacin concentration by using endoscopic biopsy.

Results: A total of 224 patients completed follow-up. Intention-to-treat and per-protocol analyses showed that the $\mathrm{Hp}$ eradication rates of the ten-day group were $81.7 \%$ and $88.3 \%$, respectively, and the Hp eradication rates of the seven-day group were $78.3 \%$ and $83.2 \%$. No statistically significant difference was found between the two groups. The levofloxacin concentrations in the gastric mucosa of the Hp eradication failure and successful groups were $4.869 \pm 1.713$ and $7.164 \pm 2.097 \mu \mathrm{g} / \mathrm{g}$, respectively, with statistically significant differences between the two groups. The Hp eradication rate of the seven-day group of levofloxacin-based triple therapy was similar to that of the ten-day group.

Conclusions: The levofloxacin concentration in the gastric mucosa of the successful Hp eradication group was higher than that of the eradication failure group.
\end{abstract}

Keywords: Drug concentration, gastric mucosa, Helicobacter pylori, levofloxacin

\section{Terapia Triple Basada en Levofloxacina para Erradicar la Helicobacter pylori y el Efecto de la Concentración del Medicamento}

\author{
$\mathrm{YM} \mathrm{Hu}^{1,2}, \mathrm{LL} \mathrm{Luo}^{3}, \mathrm{XP} \mathrm{Hu}{ }^{3}, \mathrm{JM} \mathrm{Xu}^{3}$, L Zhang ${ }^{2,3}$
}

\begin{abstract}
RESUMEN
Objetivos: Este estudio tiene por objeto investigar sesiones de siete y diez dias de terapia triple basada en levofloxacina, así como el efecto de la concentración de la levofloxacina en una mucosa gástrica en la erradicación de Helicobacter pylori $(\mathrm{Hp})$.

Métodos: Levofloxacina (500 mg qd), esomeprazol (20 mg una oferta) y amoxicilina (1000 mg bid) fueron usados para tratar a 240 pacientes Hp-positivos con gastritis crónica. Los pacientes fueron divididos aleatoriamente en grupos de tratamiento de siete y diez días $(n=120$ en cada grupo). Las pruebas de aliento $C$ de los pacientes se revisaron cuatro semanas después del final del tratamiento de erradicación. El primer día después del tratamiento, se obtuvieron cuatro bloques de 61 pacientes del grupo de siete días para determinar la concentración de levofloxacina mediante el uso de la biopsia endoscópica. Resultados: Un total de 224 pacientes completaron el seguimiento. Los análisis de intención de tratamiento y los análisis por protocolo demostraron que las tasas de erradicación de Hp del grupo de diez días fueron de $81.7 \%$ y 88.3\%, respectivamente, y las tasas de erradicación de Hp del grupo de siete días fueron $78.3 \%$ y $83.2 \%$. No se encontró ninguna diferencia estadísticamente significativa entre los dos gru-
\end{abstract}

From: ${ }^{1}$ Department of Scientific Research,The First Affiliated Hospital of Anhui Medical University, Hefei 230032, China, ${ }^{2}$ The Key Laboratory of Digestive Disease in Anhui Province, Hefei 230032, China and ${ }^{3}$ Department of Gastroenterology, The First Affiliated Hospital of Anhui Medical University, Hefei 230032, China.
Correspondence: Dr L Zhang, Department of Gastroenterology, The First Affiliated Hospital of Anhui Medical University, The Key Laboratory of Digestive Disease in Anhui Province, Hefei 230022, China, Fax: + 86551 62923203, email: leizhangdoc@126.com 
pos. Las concentraciones de levofloxacina en la mucosa gástrica de los grupos de éxito y fracaso de la erradicación de Hp fueron $4.869 \pm 1.713$ y $7.164 \pm 2.097 \mu \mathrm{g} / \mathrm{g}$, respectivamente, con diferencias estadísticamente significativas entre los dos grupos. La tasa de erradicación de Hp del grupo de siete días de la terapia triple basada en levofloxacina fue similar a la del grupo de diez días.

Conclusiones: La concentración de levofloxacina en la mucosa gástrica del grupo exitoso en la erradicación de Hp fue mayor que la del grupo de fracaso en la erradicación.

Palabras claves: Concentración del medicamento, mucosa gástrica, Helicobacter pylori, levofloxacina

West Indian Med J 2017; 66 (1): 138

\section{INTRODUCTION}

Helicobacter pylori (referred to as $\mathrm{Hp}$ ) is the main pathogenic factor of chronic gastritis, peptic ulcer, gastric carcinoma and gastric mucosa-associated lymphoid tissue lymphoma. Helicobacter pylori eradication is important in treating peptic ulcer, preventing ulcer recurrence, alleviating gastritis symptoms and preventing cancer (1-4).

A triple regimen which consists of a proton pump inhibitor (PPI), amoxicillin, clarithromycin and metronidazole is currently the most commonly used treatment to eradicate $\mathrm{Hp}$ and has a failure rate of $20 \%$ to $30 \%(5-8)$. Antimicrobial drug resistance is an important cause of failure of Hp eradication $(9,10)$. Therefore, finding new treatments is an urgent need. According to the Maastricht IV consensus (11), levofloxacin can be used as a first-choice treatment of Hp infection. Studies (8) have shown that when the eradication regimen which contains levofloxacin was used for remedial treatment, the total eradication rate of the ten-day course was higher than that of the seven-day course. For the initial Hp treatment, few reports are available on the effect of the different courses of the levofloxacin-containing regimen on Hp eradication.

Pharmacological analysis revealed that the success of antibiotic treatment depends on the local antibiotic concentration of the treatment position. Helicobacter pylori can specifically colonize the gastric mucosa and mucosal surface. Thus, successful treatment relies on achieving an effective bactericidal concentration of antibiotics in Hp colonisation sites. However, few studies on this treatment have been reported. This study aims to compare the curative effect of the seven and ten-day course treatments of the levofloxacin-based triple regimen as initial treatment of Hp infection. The effect of the local levofloxacin concentration in the gastric mucosa on the eradication rate of $\mathrm{Hp}$ was observed.

\section{SUBJECTS AND METHODS}

\section{Inclusion criteria}

We included a total of 240 patients. All patients were diagnosed with chronic gastritis with a positive Hp through endoscopic rapid urease test or ${ }^{14} \mathrm{C}$ urea breath test. The male and female patients, whose ages ranged from 18 to 70 years, had not received formal $\mathrm{Hp}$ eradication treatment. Prior to treatment, signed informed consent was obtained from the patients. This study was conducted in accordance with the Declaration of Helsinki. This study was conducted with approval from the
Ethics Committee of Anhui Medical University. Written informed consent was obtained from all participants.

\section{Exclusion criteria}

The exclusion criteria were as follows: previous eradication treatment of $\mathrm{Hp}$; intake of antibiotics, bismuth, $\mathrm{H} 2$ receptor antagonists and proton pump inhibitor (PPI) two weeks prior to the treatment; history of allergy to penicillin or clarithromycin, intake of non-steroidal anti-inflammatory drugs, antiplatelet, anticoagulant drugs and drugs which can damage the gastric mucosa in the recent three months, patients who underwent subtotal gastrectomy, existing diseases such as severe liver disease, heart disease, kidney disease, malignant tumour and alcoholism, which may influence the evaluation and pregnant or lactating women.

\section{Rejection criteria}

The rejection criteria were disease progression or emerging severe complications, serious adverse reactions during treatment, other emerging disease interference observed during treatment and a lack of follow-up.

\section{Grouping and administration method}

The patients were randomly divided into two groups. A total of 120 patients of the seven-day course group were administered $20 \mathrm{mg}$ of esomeprazole twice daily (nexium, $20 \mathrm{mg}$ / tablet, H10980067; AstraZeneca Pty Ltd, Sweden), $1000 \mathrm{mg}$ of amoxicillin twice daily (amoxicillin, $500 \mathrm{mg} /$ tablet, H20003263; Zhuhai Union Pharmaceutical Co Ltd, Zhuhai, China) and $500 \mathrm{mg}$ of levofloxacin once daily (cola Erbitux, 0.1 g/tablet, H10980067; Beijing Double-Crane Pharmaceutical Company, Beijing, China) for seven days. The ten-day course group, which comprises 120 patients, was administered the same programme for ten days. After informed consent was obtained, four blocks of gastric antrum mucosa were cut from the patients of the seven-day group who volunteered for the detection of levofloxacin concentration by using highperformance liquid chromatography (HPLC).

\section{Collection and treatment of gastric mucosa specimen}

On the first day after the seven-day levofloxacin-based triple therapy, the subjects underwent endoscopic examination. Four blocks of gastric antrum mucosa were obtained and weighed by using electronic scales. The surface of each detected gastric mucosa was washed with physiological saline dried, 
ground and weighed. The homogenate was diluted to 1:9 with saline and gastric mucosal homogenates were centrifuged at $5000 \mathrm{rpm}$ for ten minutes in a refrigerated centrifuge. Then, the supernatant was harvested, and the same volume of trichloroacetic acid was added to precipitate the protein. The mixture was vortexed for two minutes and centrifuged at $12000 \mathrm{rpm}$ for 10 minutes in a refrigerated centrifuge. A total of $20 \mu \mathrm{l}$ of supernatant was obtained for concentration analysis.

\section{High-performance liquid chromatography analysis} Levofloxacin standard (purity $>99.9 \%$ Lot: BCBF7004V) and acetonitrile HPLC grade were purchased from Sigma and Tedia (USA), respectively. Levofloxacin concentration was analysed by using Agilent 1100 HPLC.

The chromatographic conditions were as follows: column, Hypersil ODS C18 (4.6 mm $\times 250 \mathrm{~mm}, 5 \mu \mathrm{m})$, oven temperature, $40{ }^{\circ} \mathrm{C}$, mobile phase, acetonitrile, $50 \mathrm{mmol}^{-1} \mathrm{~L}^{-1}$ citric acid, 1 mol.L-1 ${ }^{-1}$ ammonium acetate, 27;72:1 flow rate, 1.0 $\mathrm{mL} \cdot \mathrm{min}^{-1}$, UV detection wavelength, $295 \mathrm{~mm}$ and injection volume, $20 \mu \mathrm{L}$.

Within the range of $0.1 \mathrm{mg} . \mathrm{L}^{-1}$ to $2.0 \mathrm{mg} . \mathrm{L}^{-1}$, the tissue concentrations of levofloxacin $(\mathrm{C})$ exhibited a good linear relationship with the peak areas (Y). The standard regression equation was $y=66.78 \mathrm{x}-0.974, r=0.9993(n=7)$ with LOD as $0.1(\mathrm{~S} / \mathrm{N}=3), 0.2,0.8$ and $1.6 \mathrm{mg} . \mathrm{L}^{-1}$. The intra- and inter-day $\mathrm{RSD}$ were all $<10 \%$, with a relative recovery rate of $>80 \%$.

\section{Therapeutic evaluation}

A week prior to enrolment, Hp infection was diagnosed based on Hp-positive results obtained by the endoscopic rapid urease test or the ${ }^{14} \mathrm{C}$ urea breath test. After four weeks of treatment, ${ }^{14} \mathrm{C}$ urea breath test with negative $\mathrm{Hp}$ was diagnosed as $\mathrm{Hp}$ eradication.

\section{Therapeutic evaluation items}

The patients were examined before the treatment, seven to ten days after the treatment and four weeks after termination of administration. Symptoms, improvements, medications and adverse reactions were recorded in detail.

\section{Statistical analysis}

SPSS 13.0 software was used for statistical analysis. Intention-to-treat (ITT) and per-protocol (PP) analyses were carried out to evaluate the Hp eradication rate. Clinical data, Hp eradication rate and gastric mucosa concentration of the two groups were compared by performing $t$-test, $\chi^{2}$ test and $t$-test on an independent sample, respectively.

\section{RESULTS}

\section{General data}

A total of 240 patients were enrolled, including 106 males and 134 females aged 18 to 65 years. In the seven-day group, 113 patients completed treatment and follow-up examination and seven patients did not complete follow-up. In the ten-day group, 111 patients completed treatment and follow-up examination and nine patients did not complete follow-up. The difference between the patients' age, gender, smoking, alcohol consumption and proportion of compliances of the two groups exhibited no statistical significance $(p>0.05)$, as shown in Table 1.

Table 1: Comparison of basic data between the two groups

\begin{tabular}{lcc}
\hline & $\begin{array}{c}\text { Seven-day treatment group } \\
(\mathbf{n}=\mathbf{1 2 0})\end{array}$ & $\begin{array}{c}\text { Ten-day treatment group } \\
(\mathbf{n}=\mathbf{1 2 0})\end{array}$ \\
\hline Age (year) & $43 \pm 10$ & $44 \pm 11$ \\
Gender (M/F) & $51 / 69$ & $55 / 65$ \\
Smoker & 35 & 28 \\
Drinker & 30 & 25 \\
Compliance & $94.2 \%(113 / 120)$ & $92.5(111 / 120)$ \\
\end{tabular}

Comparison of the data between the two groups, $p>0.05$

\section{Comparison of Hp eradication}

Intention-to-treat and per-protocol analyses showed that the absolute value of the Hp eradication rate of the ten-day group was higher than that of the seven-day group, but the differences were not statistically significant (Table 2).

Table 2: Comparison of the Helicobacter pylori eradication rate between the two groups

\begin{tabular}{lll}
\hline & Seven-day treatment group & Ten-day treatment group \\
\hline ITT & $78.3 \%[94 / 120](70.9 \sim 85.8)$ & $81.7 \%[98 / 120](74.6 \sim 88.7)$ \\
PP & $83.2 \%[94 / 113](69.1 \sim 84.9)$ & $88.3 \%[98 / 111](72.7 \sim 87.7)$ \\
\hline
\end{tabular}

Note: The values in the parentheses were the confidence interval of the $H$ py-lori eradication rate. The values in the square brackets were cases of $H$ pylori eradication/total cases. Comparison of the data between the two groups, $p>0.05$

\section{Effect of gastric mucosa levofloxacin concentration on $\mathrm{Hp}$ eradication}

In the seven-day group, 61 patients completed levofloxacin concentration detection and follow-up examination. The results showed that eradication was successful in 51 patients and failed in 10 patients. The average levofloxacin concentrations in the gastric mucosa of patients with successful Hp eradication and failed Hp eradication were $7.164 \pm 2.097 \mu \mathrm{g} / \mathrm{g}(0.796 \pm$ $0.233 \mu \mathrm{g} / \mathrm{mL})$ and $4.869 \pm 1.713 \mu \mathrm{g} / \mathrm{g}(0.541 \pm 0.190 \mu \mathrm{g} / \mathrm{mL})$, respectively. The levofloxacin concentration of patients with successful Hp eradication was higher than that of patients with failed Hp eradication. The difference between the two groups was statistically significant $(p=0.005)$.

\section{Safety evaluation}

A total of nine and 12 patients from the seven and ten-day groups of levofloxacin-based triple therapy, respectively, had adverse reactions. The main adverse reactions were nausea, vomiting, a bitter taste, dizziness, headache, diarrhoea and weakness, which were all mild and did not influence the completion of treatment. The comparison of the adverse reaction 
between the two groups had no significant difference $(p=0.372)$.

\section{DISCUSSION}

According to the Maastricht IV consensus (11), levofloxacin can be used for Hp eradication therapy and prolonging treatment duration improves Hp eradication rate. This study compared the Hp eradication effect of seven and ten-day courses of levofloxacin triple therapy. The Hp eradication rate of the seven-day course therapy was similar to that of the ten-day course therapy without significant difference. The failure of the ten-day course therapy to significantly improve the eradication rate of Hp may be attributed to the high resistance rate of levofloxacin in China. Song et al (12), reported that China's levofloxacin resistance rate is $30 \%$ to $38 \%$. The failure may also be due to levofloxacin dosage. The levofloxacin dose is $500 \mathrm{mg}$ bid for $\mathrm{Hp}$ eradication in the foreign literature and the Hp eradication rate is about $90 \%(13,14)$.

Pharmacological analysis demonstrated that the treatment is successful when antibiotics attain an effective bactericidal concentration in Hp colonisation sites. Hp eradication is closely associated with the minimum inhibitory concentration (MIC) of levofloxacin in Hp strain. A related study (15) conducted in China showed that the levofloxacin MIC in Hp strain ranges from $0.0625 \mu \mathrm{g} / \mathrm{mL}$ to $8.00 \mu \mathrm{g} / \mathrm{mL}$. This study compared the levofloxacin concentrations in the gastric mucosa of the successful and the failed Hp eradication groups. The levofloxacin concentration of both groups achieved the levofloxacin MIC in the Hp strain. The concentration in the gastric mucosa of the successful $\mathrm{Hp}$ eradication group was higher than that of the failed Hp eradication group and no significant difference was found between the two groups. Therefore, this study showed that $500 \mathrm{mg}$ of levofloxacin once daily can achieve effective anti-Hp effect in the stomach. A higher concentration of levofloxacin in the gastric mucosa corresponds to easier Hp eradication. Increasing the levofloxacin dose may partly overcome the effect of levofloxacin resistance.

Patients with the same $\mathrm{Hp}$ eradication programmes had different levofloxacin concentrations in the gastric mucosa. This finding may be due to differences in levofloxacin gastric mucosal transport. Studies have shown that levofloxacin has active transport characteristics in the kidney (16), intestine (17, 18 ) and the placental barrier (19). P-glycoprotein and organic cation transporters (OCT) inhibitors are the definite participating transporters. However, studies on gastric transporters are limited. Further research and exploration are necessary to investigate whether the levofloxacin transport is active and whether the participating transporters have individual differences, thereby causing varying concentrations.

\section{ACKNOWLEDGEMENTS}

This Project was supported by the National Natural Science Youth Foundation of China (Grant No. 81100269).

\section{REFERENCES}

1. Bontems P, Kalach N, Vanderpas J, Iwanczak B, Casswall T, Koletzko S et al. Helicobacter pylori Infection in European Children with Gastroduodenal Ulcers and Erosions. Pediatr infect Dis J 2013; 32: 1324-9.

2. Lehours P, Zheng Z, Skoglund A, Mégraud F, Engstrand L. Is there a link between the Lipopolysacchar-de of Helicobacter pylori gastric MALT lymphoma associated strains and lympho-mapathogenesis? PLoS One 2009; 4: e7297.

3. Chuah SK, Tsay FW, Hsu PI, Wu DC. A new look at anti-Helicobacter pylori therapy. World J Gastroenterol 2011; 17: 3971-5.

4. Kuo CH, Hsu PI, Kuo FC, Wang SS, Hu HM, Liu CJ et al. Comparison of 10 day bismuth quadruple therapy with high-dose metronidazole or levofloxacin for second-line Helicobacter pylori therapy: a randomized controlled trial. J Antimicrob Chemother 2013; 68: 222-8.

5. Hsu PI, Wu DC, Wu JY, Graham DY. Is there a benefit to extending the duration of Helic-obacter pylori sequential therapy to 14 days? Helicobacter 2011; 16: 146-52.

6. Graham DY, Fischbach L. Helicobacter pylori treatment in the era of increasing antibiotic resistance. Gut 2010; 59: 1143-53.

7. Graham DY, Lu H, Yamaoka Y. A report card to grade Helicobacter pylori therapy. Helicobacter 2007; 12: 275-8.

8. Gisbert JP, Morena F. Systematic review and meta-analysis: levofloxacinbased rescue regimens after Helicobacter pylori treatment failure. Aliment Pharmacol Ther 2006; 23: 35-44.

9. Wu DC, Hsu PI, Wu JY, Opekun AR, Kuo CH, Wu IC et al. Sequential and concomitant therapy with four drugs is equally effective for eradication of H. pylori infection. Clin Gastroenterol Hepatol 2010; 8: 36-41.

10. De Francesco V, Giorgio F, Hassan C, Manes G, Vannella L, Panella C et al. Worldwide H. pylori antibiotic resistance: a systematic review. J Gastrointestin Liver Dis 2010; 19: 409-14.

11. Malfertheiner P, Megraud F, O’Morain CA, Atherton J, Axon AT, Bazzoli F et al. Management of Helicobacter pylori infection-the Maastricht IV/ Florence Consensus Report Gut 2012; 61: 646-64.

12. Song Z, Zhou L, Xue Y, Bai P, Lin S, He L et al. A study to explore HP antibiotic resistance and efficacy of eradication therapy in China (multicenter, nation-wide, randomized, control study) Helicobacter 2011; 16: 117-8.

13. Schrawen RW, Janssen MJ, de Boer WA. Seven-day PPI-triple therapy with levofloxacinis very effective for Helicobacter pylori eradication. Neth J Med 2009; 67: 96-101.

14. Gisbert JP, Fernández-Bermejo M, Molina-Infante J, Pérez-Gallardo B, Prieto-Bermejo AB, Mateos-Rodríguez JM et al. First-line triple therapy with levofloxacin for Helicobacter pylori eradication. Aliment Pharmacol Ther 2007; 26: 495-500.

15. Zou J, Yang ZX, Qin ZM. Laboratory and clinical study of levofloxcain against Helicobacter pylori. Zhonghua Yi Xue Za Zhi 2003; 83: 1778-81.

16. Ito T, Yano I, Hashimoto Y, Inui K. Transepithelial transport of levofloxacin in the isolated perfused rat kidney. Pharm Res 2000; 17: 23641.

17. Yamaguchi H, Yano I. Pharmacokinetic role of P-glycoprotein in oral bioavailability and intestinal secretion of grepafloxacin in vivo. J Pharnacol Expther 2002; 300: 1063-9.

18. Swoboda S, Oberdorfer K, Klee F, Hoppe-Tichy T, von Baum H, Geiss HK. Tissue and serum concentrations of levofl- oxacin $500 \mathrm{mg}$ administered intravenously or orally for antibiotic prophylaxis in biliary surgery. J Antim Chemo 2003; 51: 459-62.

19. Polachek H, Holcberg G, Polachek J, Rubin M, Feinshtein V, Sheiner E et al. Carrier-mediated uptake of levofloxacin by BeWo cells, a human trophoblast cell line. Arch Gynecol Obstet 2010; 281: 833-8. 